\title{
Standar Asuhan Keperawatan Dengan Kesiapan Peningkatan Pengetahuan
}

\author{
Jek Amidos Pardede \\ jekpardedemi@rocketmail.com
}

\section{A. Pengertian}

Kesiapan peningkatan pengetahuan adalah adanya atau pemerolehan informasi kognitif yang berhubungan dengan topik tertentu yang memadai untuk memenuhi tujuan terkait kesehatan dan dapat ditingkatkan (Nanda, 2011)

\section{B. Tanda dan Gejala}

1. Kognitif (Doenges, et.al, 2008, Kim, 2006)

a. Menyatakan ketertarikan untuk belajar sesuatu

b. Mengungkapkan pengetahuan tentang topik tertentu, menggambarkan pengalaman yang lalu terkait dengan topik tersebut

2. Afektif

a. Merasa senang dengan pengetahuan tentang suatu topik yang diketahui saat ini

b. Reaksi emosi sesuai dengan stressor yang dialami

3. Fisiologis

a. Mampu mendengarkan pesan dengan baik

b. Tidak ada keringat dingin pada saat melakukan aktivitas perawatan diri

c. Tidak ada kelemahan, kelumpuhan atau kekakuan yang dapat menghambat pergerakan saat melakukan perawatan diri

4. Sosial

a. Menanyakan atau meminta informasi tentang upaya yang dilakukan untuk meningkatkan kesehatannya

b. Tidak ada kesulitan untuk melakukan hubungan sosial dengan orang lain (mempunyai teman dekat)

c. Dapat menjawab pertanyaan sesuai kehendak perawat

5. Perilaku (NANDA, 2011)

a. Perilaku meminta informasi tentang suatu topik, menanyakan sesuatu hal

b. Selama wawancara dapat duduk dengan tenang dan tampak ketertarikan untuk mendengarkan

c. Tidak ada perilaku bermusuhan, histeris, agitasi atau apatis selama wawancara 
d. Perilaku sesuai dengan pengetahuan yang diungkapkan

e. Menjelaskan pengetahuan tentang topik tertentu

\section{Intervensi Keperawatan}

Menurut Doengoes, Moorhouse dan Murr. (2008) intervensi generalis yang dapat dilakukan pada individu dalam mengatasi kesiapan peningkatan pengetahuan untuk meningkatkan pengetahuan individu antara lain:

1. Tujuan

a. Klien menunjukkan responsibility untuk belajar ditandai oleh ketertarikan

/semangat pada saat menjawab setiap pertanyaan

b. Klien mampu mengidentifikasi sumber informasi yang akurat

c. Klien secara aktif mengungkapkan secara verbal informasi yang dapat digunakannya

d. Klien dapat menggunakan informasi yang diperoleh dalam mengembangkan rencana individu untuk meningkatkan kesehatan atau mencapai tujuan

2. Intervensi generalis

a. Bersama individu kembangkan perencanaan untuk belajar:

1) Verikasi tingkat pengetahuan individu tentang suatu topik

2) Tentukan motivasi dan besarnya harapan individu untuk dalam belajar

3) Bantu individu mengidentifikasi tujuan dari pembelajaran

4) Pastikan metode pembelajaran yang disukai (misal: auditory, visual, interaktif, tangan)

5) Identifikasi dan dan catat faktor interpersonal yang dapat mempengaruhi pembelajaran (misal: umur/tingkat perkembangan, jenis kelamin, pengaruh budaya/sosial, agama, pengalaman hidup, tingkat pendidikan)

6) Tentukan hal-hal yang dapat mengganggu pembelajaran (misal: individu tidak dapat membaca, pembicaraan atau bahasa yang digunakan individu dengan tenaga kesehatan lain, disleksia), faktor fisik (misal: defisit sensory, seperti gangguan dalam pendengaran dan penglihatan, aphasia), fisik yang tidak stabil (misal: sakit akut, intoleransi aktivitas), gangguan material dalam pembelajaran.

b. Fasilitasi pembelajaran:

1) Berikan informasi dalam format yang bervariasi dan tepat pada gaya pembelajaran individu (misal: audiotape, booklet, video, kelas/seminar, internet) 
2) Berikan informasi sumber informasi yang dapat dijadikan bahan pembelajaran

(misal: bibliography dan webset)

3) Diskusikan jalan atau cara untuk mengetahui sumber informasi yang akurat

4) Identifikasi sumber komunitas dan kelompok yang tepat yang dapat memberikan informasi.

\section{DAFTAR PUSTAKA}

1. Doenges, M.E, Moorhouse, M.F dan Murr, A,C. (2008). Nurse's Pocket Guide Diagnoses, Prioritized Interventions, and Rationals. Edition 11. Philadelphia. F.A Company

2. Hidayat, D.R. (2009). Pengantar Psikologi untum Tenaga Kesehatan Ilmu Perilaku Manusia. Cetakan I. Jakarta: Penerbit Trans Info Media

3. Pardede, J. A. (2020). Teori Dan Model Adaptasi Sister Calista Roy: Pendekatan Keperawatan.

4. NANDA. (2011). Diagnosis Keperawatan Definisi dan Klasifikasi 2009-2011 (terjemahan). Cetakan I. Jakarta. Penerbit Buku Kedokteran EGC

5. Sinaga, T. R., \& Pardede, J. A. (2021). Pengetahuan dan Sikap dengan Tindakan Ibu dalam Pola Makan pada Anak Autis. Jurnal Ilmiah Permas: Jurnal Ilmiah STIKES Kendal, 11(1), 77-84.

6. FIK UI. (2011). Draft Scaning 33 Diagnosa Keperawatan Jiwa. Tidak dipublikasikan

7. Pardede, J. A. (2020). Terapi Keluarga.

8. Kim, M.J, McFarland, G.K, Mclane, A.M. (2006). Diagnosa keperawatan.(terjemahan). Edisi 7. Jakarta: Penerbit Buku Kedokteran EGC 
